\title{
A Tese da Singularidade Brasileira Revisitada: Desafios Teóricos Contemporâneos*
}

\author{
Sergio B. F. Tavolaro
}

Professor-adjunto do Departamento de Sociologia e do Programa de Pós-Graduação em Sociologia da Universidade de Brasília (UnB), Brasília, Distrito Federal, Brasil. E-mail:sergiotavolaro@hotmail.com

\section{A TESE DA SINGULARIDADE BRASILEIRA E SUAS INSINUAÇÕES}

$\mathrm{V}$ islumbrada desde pronto como singular em relação a outras, a sociedade brasileira é amplamente assumida como um objeto de investigação privilegiado, merecedor de esforços explicativos e interpretativos específicos; não raro, num movimento quase imediato, ela se vê alçada da condição de unidade de análise ao status de categoria analítica. Com efeito, a tese da singularidade brasileira revela-se a ideiaforça mais poderosa e penetrante de nosso pensamento social. Mesmo uma breve apreciação é facilmente capaz de revelar sua força percuciente e sua notável presença em diferentes momentos e seções desse universo intelectual: como nenhuma outra, ela tem logrado circunscrever e orientar a agenda de reflexão, pesquisa e elucubração acerca da experiência social brasileira. Conquanto se reconheça as irredutíveis

\footnotetext{
* Este artigo é resultado de reflexões realizadas no âmbito de um projeto de pesquisa financiado pela Bolsa de Produtividade do Conselho Nacional de Desenvolvimento Científico e Tecnológico (CNPq), nível 2 e pelo Edital 43/2013 também do CNPq. Uma primeira versão do artigo foi apresentada no $37^{\circ}$ Encontro Anual da Associação Nacional de Pós-Graduação e Pesquisa em Ciências Sociais (Anpocs), na Sessão Temática "Teoria Social no Limite". Agradeço a Frédéric Vandenberghe e Artur Perrusi, coordenadores da $\mathrm{ST}$, bem como as críticas e sugestões então recebidas. Agradeço também a leitura criteriosa e arguta dos pareceristas anônimos de DADOS - Revista de Ciências Sociais, cujas recomendações procurei atender.
}

DADOS - Revista de Ciências Sociais, Rio de Janeiro, vol. 57, no-3, 2014, pp. 633 a 673. 
peculiaridades dos vários autores e constelações intelectuais que coloriram esse cenário, admitida até mesmo a incomensurabilidade das distintas ancoragens epistemológicas - algumas das quais notoriamente anacrônicas - sobre as quais se apoiaram diagnósticos diversos dessa pretensa peculiaridade societal, tal ideia parece permanecer irresistivelmente hegemônica. O presente artigo pretende revisitar essa tese, abordá-la em algumas de suas principais manifestações e modulações com o propósito inicial de identificar os elementos que a consubstanciam. Ao invés de deixar-se seduzir por seu notável poder de emoldurar o real, cedendo aos seus apelos e noções, é tempo de interpelá-la com distanciamento. Com esse objetivo, minha opção metodológica é abordá-la a partir de algumas dentre as mais célebres obras e esforços de "interpretação do Brasil", restringindo-me, dessa maneira, à sua circulação acadêmico-intelectual.

Algumas advertências prévias fazem-se necessárias: ao inquirir essa tese, tratarei suas manifestações acerca da "singularidade brasileira" como uma espécie de discurso que, se por um lado, não guarda com a realidade à qual pretende referir-se uma relação de estranhamento, também não lhe é contíguo. Dito de outro modo, não a tomo nem como uma falsa construção da experiência brasileira, nem como um canal de acesso privilegiado a essa experiência. Interessa-me, sim, investigar como ela serve-se de vários pontos e aspectos da realidade para confirmar suas próprias proposições. Mas interessa-me também inquirir a respeito do quadro de referência sobre o qual tal tese se apoia. Explico-me: não a considero autossuficiente em suas reivindicações de verdade; conforme minha primeira hipótese, a imagem do Brasil contemporâneo como um cenário especial e original não é fabricação exclusiva e solitária dessa tese ${ }^{1}$. A meu ver, suas proposições assentam-se e circulam no interior de um terreno epistemológico mais amplo, caro ao próprio imaginário sociológico da modernidade ${ }^{2}$.

De acordo com minha segunda hipótese, esse terreno epistemológico restringe sobremaneira as possibilidades de imaginação sociológica em uma direção bastante específica: de maneira expressiva, as alternativas de interpretação confluem no sentido de se vislumbrar a experiência brasileira como diversa daquelas tidas por modelares da modernidade. Mas esses dois pontos não exaurem o problema em tela. É mais que evidente que as últimas décadas testemunharam a multiplicação de críticas desferidas contra certo discurso a respeito da experiência moderna. Disseminaram-se as ocasiões nas quais a reafirmação 
e o reforço tout court de parâmetros sociológicos por muito tempo estáveis deram lugar a observações quanto aos seus limites e fragilidades. Se, conforme sugere a primeira hipótese do artigo, a tese da singularidade brasileira adota aqueles como seus próprios parâmetros, é de se esperar que sua desestabilização redunde em desafios decisivos às maneiras como nossa suposta originalidade tem sido comumente imaginada e codificada. Ou seja, à fragilização do discurso sociológico hegemônico da modernidade se seguiriam inevitavelmente questionamentos àquela tese.

Esse desdobramento será foco especial de minhas atenções. Há algo mais, porém, que desejo explorar: talvez com alguma dose de ironia, conforme minha terceira hipótese, é possível identificar nas mais célebres obras interpretativas da "peculiaridade brasileira" - as mesmas que esposam elementos centrais daquela tese - antecipações a críticas contemporâneas ao discurso da modernidade. As possibilidades dessas antecipações encontram-se associadas à posição não hegemônica de enunciação de tais intérpretes, que lhes permitiu vislumbrar a experiência moderna de ângulos incomuns às posições hegemônicas. Por mais assistemáticas que se apresentassem, por mais divorciadas que estejam em relação às terminologias científicas atualmente em voga, os sentimentos de descompasso entre a realidade brasileira e os parâmetros da modernidade, recorrentes em nosso universo intelectual, podem ser tomados como índices das fragilidades do discurso sociológico da experiência moderna a que me referi há pouco. Pretendo debruçar-me sobre tais desencontros também com o propósito de avaliar as reações e as respostas da tese da singularidade brasileira nesse debate contemporâneo.

\section{AINDA O PROBLEMA DAS ORIGENS E USOS DE NOSSAS IDEIAS}

Muito já se debateu acerca da caracterização que Silvio Romero ofereceu para o clima intelectual brasileiro da segunda metade do século XIX: "Um bando de ideias novas esvoaçava sobre nós de todos os pontos do horizonte" (Romero, 1926 apud Schwarcz, 1993:27). Em uma das passagens lapidares de Raízes do Brasil, Sérgio Buarque desfecha um argumento expressivo de certo desconforto recorrente entre nossos intérpretes: "Trazendo de países distantes nossas formas de convívio, nossas instituições, nossas idéias, e timbrando em manter tudo isso em ambiente muitas vezes desfavorável e hostil, somos ainda hoje uns desterrados em nossa terra" (Holanda, 1994:3). Sugestivo do vigor du- 
radouro desse sentimento, tal preocupação foi reavivada em décadas recentes por pesquisadores que retomaram as reflexões acerca das fontes de nossas referências cognitivas, morais, estético-expressivas e institucionais. É possível que nenhuma outra expressão tenha conseguido captar de maneira tão precisa essa angústia como "ideias fora do lugar", objeto da análise magistral de Roberto Schwarz. Como bem sabemos, ao empregá-la Schwarz - que também se dobra àquela passagem de Raízes do Brasil - visava investigar o enorme paradoxo (ou descompasso) que parecia fraturar a sociedade brasileira do século XIX: ao mesmo tempo que o ideário liberal adentrava o imaginário de nossas elites com passos firmes, o corpo social continuava a descansar sobre a mais abjeta das instituições, a escravidão. Em sua visada, não havia dúvidas quanto à origem estrangeira daquelas referências - afinal, "havíamos conquistado a independência há pouco, em nome de idéias francesas, inglesas e americanas" (Schwarz, 2009a:63); mas parecialhe também evidente que sua aplicação no Brasil seguia uma lógica diferente.

Mais recentemente, Ventura corroborou essa avaliação ao se debruçar sobre a "recepção de modelos europeus, como a história natural e a etnologia, que forneceram instrumentos para a interpretação da natureza tropical e das raças e culturas brasileiras" (1991:12-13; ênfases no original) naquele mesmo cenário analisado por Schwarz. A seu ver, com algum lapso temporal, além de "deslocados de suas funções de origem" (ibidem:40), esses modelos teriam sido adotados em meio a esforços de afirmação da identidade nacional por "camadas letradas e dirigentes". Ocorre que, para Ventura, o nacionalismo exacerbado de certos críticos literários, ansiosos por bradar as inovações das criações nacionais, os teria impedido de perceber certa armadilha eurocêntrica da qual caíam presas: a adoção desses parâmetros europeus implicava a exotização da autorrepresentação brasileira, resultado de um olhar de fora projetando-se a partir de dentro. A bem da verdade, na percepção de Schwarz, nada disso nos autorizaria a concluir que tais "ideias estrangeiras" pouco ou nada diziam acerca desse país periférico e de tradição ibérica. Sendo aceitas como suas, essas mesmas referências "assim faziam parte da nossa identidade" (Schwarz, 2009a:63), ainda que num primeiro momento somente para círculos sociais restritos, ou apenas no âmbito das relações desses círculos com outras parcelas da sociedade. Destarte, aquelas referências estrangeiras passavam a cumprir importantes funções locais na organização e funcionamento dessa sociedade capitalista periférica. É claro que, para Schwarz, nada disso anu- 
lava inconfundíveis peculiaridades: escravidão e favor - este último um mecanismo de mediação universal - estavam lá para lembrar que, naquelas circunstâncias, o casamento entre liberalismo e sociedade brasileira jamais poderia adquirir perfil similar ao observado nas principais sociedades europeias. Destoando assim do "centro", era inevitável "o desacordo entre a representação e o que, pensando bem, sabemos ser o seu contexto" (Schwarz, 2009a:75-76). Por certo, não caberia desconsiderar a "falsidade" do liberalismo na própria Europa, isto é, seu papel ideológico. No Brasil, entretanto, o problema seria de outra ordem, em virtude de suas irredutíveis especificidades econômicas, culturais, políticas e sociais, amplamente consideradas: graças a elas, o liberalismo atuava como uma versão também original daquela "falsidade".

Seja antes ou depois de seu tratamento por Schwarz, o cerne dessa reflexão já foi alvo de inúmeras e variadas reações ${ }^{3}$. Há, no entanto, uma problematização especialmente cara aos objetivos deste artigo, a saber, o argumento conforme o qual, ao invés de mera assimilação passiva/imitativa, os processos de deslocamento de "ideias estrangeiras" e seu posterior reposicionamento em terras brasileiras fizeram-se acompanhar de significativos ajustes e transformações. Também nesse caso, o argumento não é em hipótese alguma novo. Silvio Romero já havia sugerido que "a civilização na América respectivé no Brasil, é um processo de aclimação e, inevitavelmente, de transformação da cultura européia" (Romero, 1949:296; ênfases no original). Muito tempo depois, Cruz Costa fez afirmações semelhantes ao analisar a cena intelectual brasileira na qual o mesmo Romero fora personagem destacado. Em decorrência da "importação variada de ideias e doutrinas aparentemente contraditórias" (Cruz Costa, 1964:272), o ecletismo parecia-lhe um dos traços mais marcantes de nosso universo intelectual. Mas aquilo que Cruz Costa queria sublinhar de maneira especial era o caráter dinâmico dessa recepção, que o levava a concluir que "escrever a história de suas idéias é descrever as modificações de idéias estrangeiras importadas para o Brasil" (ibidem:3-4). Sob a "influência das novas condições", aquelas ideias originariamente europeias teriam sofrido mudanças e inovações.

A expressão que possivelmente melhor captura o espírito dessas ponderações, e que em certa medida agrega maior complexidade à noção de "ideias fora do lugar" é "a originalidade da cópia". Fernando Henrique Cardoso adotou-a para avaliar as contribuições do pensa- 
mento Cepalino. Com sua atenção voltada à questão do desenvolvimento econômico da América Latina, Cardoso não pretendeu, em hipótese alguma, descartar as "raízes extracontinentais" (marxistas) das "mais originais interpretações latino-americanas" (1980:18). Ainda assim, haveria aqui "um campo teórico próprio, embora limitado" (ibidem:72), resultado de experiências sociais também singulares. Alfredo Bosi refere-se a operações de filtragem de ideologias provenientes de culturas estrangeiras, as quais permitiriam a certos grupos sociais "descartar os seus aspectos impertinentes e utilizar aqueles que interessam à racionalização de seus interesses particularistas" (1995:22; ênfases no original). Em direção análoga, Lilia Schwarcz empregou aquela mesma expressão para se referir às várias modalidades de adoção que modelos evolucionistas europeus tiveram no Brasil da segunda metade do século XIX e início do seguinte. Conforme salienta Schwarcz, exercícios de tradução dessa natureza via de regra envolviam a "seleção prévia de textos e escolhas de certos autores" (1993:42). Por essa razão, ao invés de tomar o resultado desse movimento como uma "cópia desautorizada", mais apropriado seria percebê-lo em "seus novos significados contextuais, bem como verificar sua relação com a situação social, política, econômica e intelectual vivenciada no país" (ibidem:242).

Não se quer desconsiderar o vigor dessas análises. Sua sofisticação habilita-as a apreender elementos importantes da circulação de referências caras ao imaginário acerca da experiência da modernidade no Brasil. Note-se que, dentre as mais bem-sucedidas, não há ocasião em que o retrato oferecido seja estanque ou simplificador. Ao mesmo tempo, porém, é indisfarçável a segurança com que essas mesmas análises imputam selos de origem estrita a tais "ideias". É verdade que os contextos de circulação são comumente pensados em suas relações mútuas: tal qual em nossos melhores intérpretes, a imagem da "peculiaridade brasileira" não se confunde com a do pretenso isolamento dessa experiência. Ainda assim, assume-se desde pronto a existência de fronteiras bastante precisas entre, de um lado, sociedades produtoras de referências (cognitivas, ético-morais, estético-expressivas e institucionais) e, de outro, sociedades destinatárias - sejam elas tomadas como receptoras passivas ou, no melhor dos casos, como provocadoras de mudanças mais ou menos criativas de "ideias fabricadas alhures".

Ora, observadas com distanciamento, ao menos três coisas podem ser destiladas dessas análises e reflexões: primeiramente, supõe-se que formas de pensar únicas ascendem e projetam-se a partir de configurações sociais específicas; no limite, é como se houvesse uma correspon- 
dência necessária entre contextos determinados e certos universos mentais e normativos. Nesses termos, quando empregadas ou aplicadas a outras configurações societais, essas formas de pensar e agir deveriam inevitavelmente sofrer algum tipo de ajuste, para não dizer "deformação" ou "distorção".

Em segundo lugar, apesar de se descartar a existência de entidades sociais insuladas e autossuficientes em favor do reconhecimento de suas interconexões (históricas, políticas, culturais, simbólicas, econômicas e de outras naturezas); mantém-se de maneira mais ou menos sutil certo lastro nacional a esse quadro de referência. Por conseguinte, pressupõe-se já de partida que as experiências nacionais guardam algum tipo de coerência no tempo, a despeito de eventuais fraturas internas cuja gravidade, no entanto, não fere sua condição de categoria analítica. Trava-se, dessa maneira, um pacto silencioso - e bastante eficaz em seus efeitos interpretativos - entre o observador e seu objeto, unidos graças à existência prévia e indubitável de uma dada vida nacional (com alguma frequência compartilhada por ambos). Tomada como o resultado da combinação peculiar entre elementos diversos (alguns dos quais derivados dos "países centrais", outros tantos pretensamente típicos e únicos ao novo lugar), não é de estranhar, pois, que a singularidade brasileira seja pacificamente assumida como um ponto de partida - o qual, sem nenhuma surpresa, vê-se confirmado ao termo do exercício.

Por fim, como um corolário daquela divisão (estabelecida também com nuanças e graus variados de sutileza) entre sociedades produtoras e sociedades receptoras; toma-se por certo a existência de algum tipo de conexão íntima entre "ideias e referências originais da modernidade" e as "sociedades centrais". Ao fim e ao cabo, é-se levado a concluir que, em contrapartida ao ajuste fino observado nessas últimas, sobressai-se o indisfarçável descompasso das "sociedades destinatárias". Sejam quais forem as razões identificadas do desacerto - clima, raça, meio, política, cultura, economia etc., combinadas ou não entre si - há sempre algum obstáculo que se interpõe à sua consonância. No que se segue, à luz de alguns dos mais celebrados esforços de interpretação do Brasil, importa-me destilar o "núcleo duro" dessa imagem duradoura.

\section{FORMULAÇÕES EM TORNO DA "SINGULARIDADE SOCIETAL BRASILEIRA"}

Em A Idéia de Brasil Moderno, Octavio Ianni nos recorda que "A questão nacional é um tema constante no pensamento brasileiro" (1992:8). Essa 
quase obsessão traduziu-se em realizações diversas, algumas das quais posteriormente alçadas ao status de precursoras da análise sociológica no Brasil. Desde pronto, salta aos olhos a enorme variedade desses empreendimentos (Vianna, 2004:200-206). Apoiados em ancoragens epistemológicas não raro incomensuráveis, as variáveis independentes por meio das quais essas "interpretações do Brasil" buscaram compreender a "originalidade brasileira" mostraram-se muitas vezes incompatíveis. Note-se, aliás, que a autoconsciência dessa diversidade interpretativa é quase tão antiga quanto sua própria existência ${ }^{4}$. Ora, a institucionalização das ciências sociais no Brasil parece ter acentuado ainda mais o interesse pela catalogação e avaliação do teor da produção pregressa (Santos, 1978). Recentemente, Lidke (2005) ofereceu uma classificação abrangendo cinco períodos, distribuídos em duas grandes etapas: I) Etapa da herança histórico-cultural da sociologia: 1) período dos pensadores sociais / ou período pré-científico (até a década de 1920);2) período da sociologia de cátedra (1928-1935); II) Etapa contemporânea da sociologia: 1) período da sociologia científica (1930-1950);2) período de crise e diversificação (1950-1960);3) período de busca de uma nova identidade. De outro modo, Brandão descartou tentativas de periodização vinculadas a progressos na institucionalização das ciências sociais no Brasil em favor de um esforço de identificação e análise de "linhagens / famílias de pensamento", as quais interconectariam autores e obras situados em momentos diversos de nosso universo intelectual. Para ele, mais valeria discernir "'estilos' determinados, formas de pensar extraordinariamente persistentes no tempo, modos intelectuais de se relacionar com a realidade" (Brandão, 2007:29).

Não pretendo levar às últimas consequências exercícios de catalogação dessa natureza. Basta percebê-los como evidência da complexidade dessa empresa interpretativa, matizada pela expressiva diversidade de pontos de apoio - conforme salientei, muitas vezes incompatíveis e incomensuráveis entre si - por meio dos quais a "singularidade brasileira" tem sido codificada desde longa data. Ao invés de me ater a traços tidos por exclusivos de "épocas", "escolas" e/ou "linhagens" específicas, é minha prioridade iluminar uma faceta com frequência preterida: sem descartar a existência de aspectos e preocupações únicas e exclusivas a certos períodos ou seções desse universo intelectual, interessa-me identificar algumas imagens a respeito da experiência societal brasileira que perduram e atravessam essas muitas "etapas", "períodos" e/ou "famílias" de nosso pensamento. Não se trata, con- 
forme Brandão já teve oportunidade de advertir, de "enxergar sempre no novo o antigo" (2007:58), como se esse universo intelectual fosse imune a mudanças. Ocorre que abundam evidências de que a tese da singularidade brasileira alimenta certa "regularidade na dispersão", para usar uma expressão cara a Foucault (1972).

Saliento, no entanto, que o presente exercício de reflexão não pretende em hipótese alguma subestimar diferenças irredutíveis facilmente observáveis entre autores, obras, momentos e movimentos que coloriram esse quadro. Não se trata, pois, de fazer tabula rasa das maneiras notoriamente diversas por meio das quais nossos intérpretes pretenderam explicar e codificar a "peculiaridade brasileira". Conforme Lidke (2005) nos sugere, preocupações, respostas, categorias e conceitos variaram de um momento para outro na longa história desse pensamento, desde seus precursores até os praticantes da sociologia científica. Ademais, a extensa lista de intérpretes que para muitos expressa o que há de melhor nessa tradição intelectual é por si só sugestiva da incrível diversidade desse universo: Tavares Bastos, André Rebouças, Joaquim Nabuco, Silvio Romero, Tobias Barreto, Nina Rodrigues, Alberto Torres, Oliveira Vianna, Paulo Prado, Mário de Andrade, Gilberto Freyre, Sérgio Buarque de Holanda, Caio Prado Jr., Florestan Fernandes, Celso Furtado, Raymundo Faoro, Guerreiro Ramos, entre outros (Brandão, 2007; Botelho e Schwarcz, 2009). As sugestões de Brandão certamente nos poderiam instar a "investigar a existência dessas 'famílias intelectuais' no Brasil, reconhecer suas principais características formais e escavar sua genealogia" (2007:29).

Nessa direção, além de uma "família de pensamento autoritário" (Oliveira Vianna), talvez pudéssemos falar de uma "linhagem liberal" (Rui Barbosa), de uma "perspectiva conservadora" (Visconde do Uruguai), de uma "abordagem patriarcalista" (Freyre), de uma "perspectiva patrimonialista" (Faoro), de uma "nacional-desenvolvimentista" (Guerreiro Ramos), uma "periférico-dependentista" (Celso Furtado), dentre outras. Essas várias modalidades de interpretação retrataram, cada qual a seu modo (ainda que não necessariamente de maneiras excludentes), as continuidades e rupturas entre o Brasil e outros contextos: por vezes nossa "singularidade" aparece como uma situação absolutamente original, outras como a especificidade de um quadro mais amplo com o qual guardam algum grau de parentesco ${ }^{5}$.

A depender dos critérios adotados, e considerando eventuais interpenetrações e influências mútuas, além do fato de que nem todos os auto- 
res "se enquadram nesta ou naquela linhagem" (Brandão, 2007:38), outros recortes poderiam ser igualmente sugeridos com vistas à análise dessas distintas maneiras de compreender, explicar e codificar as "particularidades brasileiras". Ou seja, parece-me indiscutível que nossa alardeada "singularidade" ganhou conotações diversas em diferentes autores, seções e momentos desse pensamento. A riqueza e relevância dessa opção analítica dispensam maiores comentários. Isso posto, saliento uma vez mais que meu interesse prioritário é, antes sim, destilar certo denominador comum que tendeu a confirmar e reforçar o que Carvalho Franco chamou de "pressuposto de uma diferença essencial" entre "nações metropolitanas" e "povos coloniais" (Franco, 1976:61) - ou, como quero preferencialmente argumentar, entre o Brasil e outros contextos ditos "centrais" da experiência moderna. Conquanto muitas das nuanças desse pensamento se percam nesse exercício, acredito que a opção mais abrangente do artigo possa iluminar alguns aspectos de um dilema sociológico que nos é caro.

Conforme observado por muitos analistas contemporâneos, é justamente a partir de meados do século XIX que preocupações com os caminhos e descaminhos da nacionalidade brasileira se exprimem em novas modalidades discursivas, boa parte delas afinadas com o imaginário científico e filosófico moderno (Alonso, 2002; Botelho, 2003; Ortiz, 2006; Schwarcz, 1993). A sociedade brasileira passava, então, gradativamente a se consolidar como uma categoria analítica. Ainda que nenhuma obra ou "família intelectual" de modo algum sintetize a riqueza e a variedade que colorem esse pensamento social, gostaria de indicar algumas regularidades, isto é, certos elementos cuja recorrência contribui para consubstanciar e perpetuar a imagem da brasileira como uma experiência societal irredutível àquelas tomadas por modelares da modernidade.

Primeiramente, é comum tomá-la como uma sociedade indiferenciada, ou ao menos configurada aquém dos níveis de complexificação e diferenciação observados no chamado "núcleo moderno". Nesse sentido, a formação de uma esfera de produção da vida material autônoma, sólida e dinamizada a partir de imperativos exclusivamente econômicos se revelaria titubeante; a isso se faria acompanhar um aparato político-administrativo não menos imaturo, claudicante em suas esperadas atribuições, já que atravessado por normas e códigos diversos daqueles que melhor qualificariam tanto a burocracia moderna quanto o tipo de dominação racional-legal. Paralelamente, prevalece a 
imagem de um corpo social esgarçado, para não dizer amorfo, politicamente débil, incapaz de estruturar um âmbito de sociabilidade alternativo às esferas políticas e econômicas e, por essa razão, impossibilitado de se converter em agente independente do Estado e da economia - e deles cobrar suas aguardadas responsabilidades. Replicado em diversas outras direções, esse quadro de indiferenciação também se manifestaria, por exemplo, na ausência de uma esfera intelectual e cultural regida por códigos e imperativos próprios.

Não menos comum é a imagem de que a sociedade brasileira permanece atada a códigos e referências não de todo racionalizados. Com isso, perpetua-se a convicção de que entre nós não teria se completado de forma integral a transição de uma ordem tradicional em direção a um cenário propriamente pós-tradicional. Por um lado, há um sentimento de que concepções de mundo mágico-religiosas continuam a se fazer presentes no cotidiano de amplos segmentos da população brasileira, informando e orientando suas atitudes e comportamentos em diversas esferas de sociabilidade, sejam elas públicas ou privadas. Por outro lado, alimenta-se a noção de que os códigos de sociabilidade seculares que lograram vicejar entre nós o fizeram, no entanto, entrelaçados a normas e expectativas mútuas de comportamento não totalmente racionalizadas. Isso responderia, dentre outras coisas, pela força da presença da religião na dinâmica política e cultural dessa sociedade, influenciando processos públicos de tomada de decisão.

Outro elemento desse "núcleo duro" é a imagem de um vínculo singular entre os domínios públicos e privados. Não raro, fala-se de uma configuração da esfera doméstica por si só diversa daquela considerada modelar da vida moderna: atravessado por referências e valores patriarcais, o domínio privado brasileiro perpetuaria hierarquias tradicionais além de orientações de conduta personalistas em excesso. Logo de partida, essas características se fariam sentir nos domínios públicos ao moldarem indivíduos pouco afeitos a padrões normativos e comportamentais igualitários e impessoais. Nessa direção, alude-se também a uma relação sensivelmente porosa e fluida entre os dois domínios: na ausência de instituições e mecanismos encarregados de filtrar anseios, demandas e interesses pessoais e particulares, o funcionamento dos espaços públicos estaria viciado, com frequência raptado pelas vontades e interesses particularistas dos segmentos mais poderosos da população. 
Faz-se menção, ainda, a certa economia emocional tomada por peculiar à experiência brasileira, não menos divorciada dos padrões modernos. Trata-se, nesse caso, da imagem de uma estrutura psíquica ausente de profundidade interior, razão maior da ausência de uma subjetividade plenamente centrada. Isso explicaria a incapacidade desse "tipo psíquico brasileiro" para se destacar do mundo externo resguardando-se de seus apelos e condicionantes mais elementares -, para conter suas vontades e desejos primários e, dessa feita, internalizar padrões comportamentais metódicos e disciplinados. Daí seu descompasso diante de códigos de sociabilidade impessoais, igualitários e universalistas, bem como dos requisitos de suas instituições-chave (Estado racional-legal, economia capitalista e esfera pública democrática). Não por acaso, as figuras da pessoa jurídica, do agente econômico empreendedor e do cidadão participativo parecem estranhas aos retratos mais correntes de nosso pretenso "caráter nacional".

Por fim, fala-se que essa sociedade guarda uma relação também peculiar com o mundo natural. Se é verdade que a ideia da ruptura com a dinâmica da natureza - exemplificada de maneira especial pela capacidade técnica para sujeitá-la aos desígnios e necessidades humanos - é comumente tomada como um dos marcos fundamentais da modernidade, estaria aqui mais um sinal da singularidade brasileira. Em virtude de um conjunto de aspectos - técnicos, simbólicos, estéticos, orgânicos etc., combinados ou não entre si -, argumenta-se que amplos segmentos da população brasileira não teriam consumado totalmente essa ruptura, de modo que suas dinâmicas psíquicas e coletivas permaneceriam de alguma maneira e em alguma proporção subsumidas aos ditames do mundo natural. Assim sendo, a vida social ainda não teria conseguido constituir-se como um domínio próprio, desvinculado dos elementos da natureza.

Articulados de maneiras e em proporções variadas, esses fatores - que assumiram diferentes matizes nas muitas interpretações e momentos que marcaram nosso pensamento social - consubstanciam o núcleo da tese da singularidade societal brasileira. Sua notável recorrência concorre para sedimentar e perpetuar a imagem de que um profundo hiato separa essa sociedade daquelas tomadas por modelares da modernidade. Importa observar que os pontos de apoio centrais dessa tese não lhe são de modo algum exclusivos. Na verdade, são os mesmos sobre os quais se ergue certo discurso acerca da modernidade que ocupa posição privilegiada na sociologia: (a) diferenciação/complexificação so- 
cial; (b) secularização; (c) separação entre domínios públicos/privados; (d) subjetividade autocentrada e, finalmente; (e) divórcio entre sociedade/natureza são alguns dos principais pilares desse imaginário sociológico hegemônico (Tavolaro, 2005; 2011; 2013).

Tudo isso, é claro, faz-nos refletir sobre o legado de certas maneiras de imaginar o Brasil, sobre sua longevidade e seu peso no presente. Marcos Nobre sustenta que a partir dos anos 1980, a impossibilidade de continuação de "qualquer projeto de tipo nacional-desenvolvimentista" representou um golpe de misericórdia para o chamado "paradigma da formação", dentro do qual a nacionalidade brasileira era pensada "com seu vínculo pretensamente intrínseco a um determinado território, a uma determinada população e a uma forma específica e exclusiva de soberania" (2012:75-76). Em sentido análogo, Cardoso (2013:12) observou que encerrado o período dos "pensadores que inventaram o Brasil", sua própria geração "começou a se debruçar sobre as formas da sociedade brasileira, suas conexões internacionais e seus novos desafios". Embora concorde com Cardoso (idem) que a temática prioritária nas ciências sociais entre nós tenha gradualmente deixado de girar "ao redor da questão nacional" - a despeito, é claro, da "sobrevida do paradigma da 'formação'" (Nobre, 2012:76) em muitas análises e esforços interpretativos de hoje-, a meu ver isso não implicou necessariamente o abandono da imagem de descompasso entre a sociedade brasileira e os "países centrais da modernidade". No meu entendimento, a tese da singularidade brasileira é uma daquelas "formas de pensar extraordinariamente persistentes no tempo (...) que subsumem até mesmo os mais lídimos produtos da ciência institucionalizada, estabelecendo problemáticas e continuidades (...)" (Brandão, 2007:29) inclusive nas ocasiões em que essa sociedade é interpelada para além de suas próprias fronteiras.

No que se segue, interessa-me o fato de que nos últimos decênios multiplicaram-se as objeções teóricas bem como as contraevidências empíricas mobilizadas para desafiar as pretensões preditivas e descritivas do discurso sociológico da modernidade.

\section{ALGUNS DESAFIOS TEÓRICOS RECENTES À SOCIOLOGIA DA MODERNIDADE}

Sabemos que, para Talcott Parsons, "o tipo moderno de sociedade emergiu em uma arena evolucionária única, o Ocidente, o qual é essen- 
cialmente a área da Europa herdeira da metade ocidental do Império Romano ao norte do Mediterrâneo" (1971:1). Na produção sociológica do século XX, talvez essa tenha sido a mais sonora e vigorosa modalidade de discurso da modernidade em que diferenciação social (inclusive a separação entre âmbitos públicos e privados), secularização normativa (repousada sobre princípios gerais, abstratos e universais), ação propositivamente orientada (preocupada com a eficiência com que certos fins podem ser alcançados) e o divórcio entre a dinâmica social e a natureza aparecem como referências epistemológicas centrais. Para ele, a configuração societal moderna foi justamente aquela que conquistou grau de autossuficiência sem paralelos no que diz respeito a pelo menos seis aspectos: adaptação a um ambiente físico hipercomplexo; motivação de suas unidades de ação; controle das ações e mobilização dessas unidades para a realização de metas coletivas; manutenção de certo padrão de valores; sua integração interna e, por fim; questões de sentido vinculadas à realidade não empírica, tudo isso em um cenário marcado por pluralidade e diversidade inéditas. Esse salto evolucionário teria resultado de transformações históricas importantes, sendo as mais recentes e impactantes as revoluções industrial, democrática e educacional. Ao fim e ao cabo, mudanças estruturais teriam se traduzido em progressos em direção a níveis sistêmicos mais elevados e, por isso mesmo, mais capazes de lidar com cenários altamente complexos (interna bem como externamente considerados).

Na visão do autor, a tomar pelo bem-sucedido exemplo do Japão, essa tendência à modernização estaria ganhando alcance mundial, atingindo inclusive sociedades não ocidentais. Note-se, porém, que os padrões seletivos, desiguais e conflitivos por meio dos quais esses valores e referências (desenvolvimento econômico, independência política, algum tipo de democracia, além de educação) vinham sendo incorporados por tais sociedades não ocidentais através de suas elites (Parsons, 1971:137) seriam evidências de seu selo de origem específico bem como da posição modelar inconfundível gozada por algumas poucas sociedades do ocidente. Em apreciações mais otimistas, seria concebível ver esses descompassos diluídos tão logo tais padrões e instituições fossem incorporados pelas sociedades em transição, seja por desenvolvimentos estritamente endógenos ou como resultado de influências externas (Rostow, 1974). Ora, conquanto Parsons e outros autores expressivos do chamado "discurso sociológico hegemônico da modernidade" reivindiquem universalidade para suas categorias, conceitos, noções e retratos da experiência moderna, há que se reco- 
nhecer que suas próprias propostas também ocupam lugares particulares de enunciação. Minha intenção a seguir é mostrar que várias das críticas recentes a esse discurso buscam justamente salientar as armadilhas e insuficiências que resultam dessas (inelutáveis) posições específicas de enunciação que reclamam universalidade.

As últimas décadas testemunharam uma nova onda de insatisfação com certo imaginário sociológico, com sua autorreivindicada capacidade para descrever e explicar a experiência social contemporânea em suas inúmeras dimensões (culturais, econômicas, políticas, institucionais, epistemológicas, subjetivas, estéticas, dentre outras), processos e desdobramentos nas diversas regiões do globo. Em linhas gerais, tais desafios são dirigidos: à própria validade científica desse discurso, como também ao escopo de aplicação empírica reivindicado para suas categorias; à referência temporal que informa os retratos acerca de suas origens e desenvolvimentos; às unidades de análise adotadas para se avaliar as manifestações da experiência moderna; à real acuidade de sua estrutura conceitual, por meio da qual os graus de modernidade de configurações societais passadas e contemporâneas são aferidos e mensurados, e por fim; às imagens construídas e projetadas a respeito de seus "Outros", em contraste com as quais as peculiaridades atribuídas ao padrão de sociabilidade moderno ganham relevo. Esses desafios alcançam níveis variados de radicalidade em diferentes perspectivas: enquanto em alguns casos o que se demanda é tão somente um esforço de adequação das categorias e conceitos correntes, em outros almeja-se nada menos que a elaboração de um quadro epistemológico totalmente novo, divorciado do discurso da modernidade. Iniciarei com o polo mais brando da crítica.

Um dos efeitos do debate sobre globalização/mundialização a partir do final dos anos 1980 foi colocar em xeque o status de unidade de análise por muito tempo gozado pelas sociedades nacionais. Ainda assim, não se teria reafirmado certa linearidade embutida no imaginário sociológico da modernidade? Afinal, uma vez entendida como a resultante do aumento da extensão, intensidade e velocidade de interconexões regulares em escala transcontinental ou inter-regional (Held et al., 1999:16), a globalização parecia levar padrões sociais outrora exclusivos do Ocidente aos quatro cantos do mundo. A sociologia poderia, enfim, empregar suas referências em um mundo cada vez mais homogêneo. Mas não tardou para que se fizessem ponderações acerca dos paradoxos, assimetrias, ambivalências e contradições desses proces- 
sos (Ianni, 1996; Ortiz, 2009). Críticos contundentes ao suposto da homogeneização alertavam justamente para o equívoco de se reduzir a globalização à ideia de modernidade e/ou ocidentalização (Pieterse, 1995). Ademais, argumentava-se que o aumento das interconexões transnacionais fez-se acompanhar de novos tipos de desconexão e de fragmentação; muitas dimensões da realidade social, inúmeros segmentos da população bem como várias regiões do globo pareciam apenas tangencialmente impactados, quando não de todo excluídos de tais processos - sem falar no surgimento de modalidades inéditas de antagonismo, geradoras de identidades exclusivistas e localmente ancoradas (Friedman, 1995; Castells, 1999).

Pode-se dizer que as recentes elaborações em torno da ideia de modernidades múltiplas ambicionam contemplar tais críticas dirigidas à sociologia da modernidade, sem, no entanto, abandonar seu quadro de referência geral. Ajustes deveriam ser feitos face à recusa veemente ao pressuposto da homogeneização: em contraste com retratos monocromáticos forjados em meados do século passado, nos quais imperava o suposto da convergência progressiva entre sociedades que se urbanizavam e se industrializavam (Rostow, 1974), argumenta-se que a experiência da modernidade no mundo contemporâneo desaguou numa "multiplicidade de programas culturais" (Eisenstadt, 2000:2; 2010). Ou seja, embora o discurso sociológico da modernidade não seja de todo descartado, almeja-se abrandar seus vínculos a qualquer padrão particular ou experiência específica. Note-se que um dos argumentoschave é que "padrões ocidentais de modernidade não são as únicas modernidades 'autênticas', ainda que gozem de precedência histórica e continuem a ser um ponto de referência básico para outras" (Eisenstadt, 2000:2-3). Isso porque a expansão da modernidade para além das fronteiras de seu berço originário teria resultado em transformações mais ou menos radicais em suas premissas culturais e políticas, fruto de sua adoção seletiva em virtude de especificidades e circunstâncias locais. Por outro lado, e não menos importante, argumenta-se que em vez de monolítica e homogênea, mesmo no ocidente, a modernidade "foi desde seus começos acossada por antinomias e contradições internas" (Eisenstadt, 2000:7; Wittrock, 2000). Não por outra razão, a sociologia da modernidade é chamada a reajustar-se em resposta às crescentes variações do programa moderno originário.

Uma terceira modalidade de crítica decorre da percepção de que "a modernidade global tem (...) operado como um pano de fundo e ele- 
mento crucial para a construção da identidade nos últimos séculos." (Domingues, 2003:233) - ou, ainda, de que vivemos um momento marcado pela "vitória global" da modernidade (Dirlik, 2003:275). Nesse sentido, afirma-se que "está se tornando menos possível aos indivíduos ou grupos humanos escapar do alcance das instituições modernas" (Wagner, 2003:XIII). Como era de se esperar, essa nova ênfase levanta críticas à própria abordagem das "modernidades múltiplas". Primeiramente, rejeita-se "considerar cada país como possuidor de seu próprio modelo, circunscrito, de modernidade" (Domingues, 2003:243). Refuta-se, na mesma medida, a supervalorização de diferenças culturais sob o argumento de que convergências e semelhanças entre inúmeros contextos societais acabariam desconsideradas, já que vislumbradas desde pronto como culturalmente incomensuráveis (Schmidt, 2007). Ao mesmo tempo, variações internas a cenários específicos - inclusive subnacionais euro-americanos - seriam sistematicamente obscurecidas à sombra de uma suposta coerência cultural que lhes conferiria homogeneidade (Dirlik, 2003). Por essa razão, o protagonismo da "modernidade europeia" que tanto se desejava diluir acabaria inadvertidamente reinstaurado: ainda que às escuras, essa configuração particular voltaria a se tornar o padrão de medida das demais.

Essa proposta talvez pudesse a princípio ser interpretada como a reafirmação tout court do discurso sociológico da modernidade. Afinal, aceita-se que "a modernidade teve seu núcleo no Ocidente, onde primeiro surgiu, e então transbordou para o mundo como um todo." Ou seja, sem quaisquer subterfúgios, assume-se que "[s]eu 'centro' foi originalmente com clareza o Ocidente, em termos tanto de sua dinâmica quanto, em especial, de poder" (Domingues, 2003:251). Ademais, alude-se a um núcleo comum às experiências societais modernas, cujo alcance ampliado tornaria a modernidade contemporânea um fenômeno verdadeiramente global ${ }^{7}$. Mas note-se que tais afirmações são também acompanhadas do desejo expresso de se evitar a inexorabilidade subjacente às teorias da modernização (Domingues, 2003; Dirlik, 2003). Na esteira dos processos de descolonização após a Segunda Guerra Mundial, e tão logo a alternativa socialista ao capitalismo saiu de cena ao final do século passado, a hegemonia euro-americana sobre a modernidade viu-se diluída. Com isso, ganhou contornos cada vez mais claros um cenário "ideologicamente e organizacionalmente descentrado", habitado por vozes e experiências outrora silenciadas e invisibilizadas pelo discurso eurocêntrico da modernização (Dirlik, 2003:276). 
Atento a esses desdobramentos, Domingues (2009) fala-nos de três períodos da modernidade: a) o liberal (mais limitado à Europa e aos EUA); b) o organizado pelo Estado (que em muitos países da América Latina desdobrou-se no desenvolvimentismo e no corporativismo); e, por fim, c) o período atual marcado por profunda complexidade e pluralização da vida social. Schmidt (2012), por sua vez, argumenta que enquanto a primeira fase da modernidade (denominada "eurocêntri$\mathrm{ca}^{\prime \prime}$ ) foi um fenômeno circunscrito à Europa, a ela seguiu-se um novo quadro ("ocidentocêntrico") marcado pela perda de monopólio daquele berço originário em favor da América do Norte. Por fim, a fase atual é designada de "policêntrica" em alusão à multiplicação inédita de centros modernos, cujas inovações substantivas responderiam pelo fato deles mesmos terem se tornado referências modelares a todas as partes do globo. Ao fim e ao cabo, argumenta-se que "não podemos mais tratar a Europa e a América do Norte como sinônimos da modernidade. Ao invés disso, para compreendermos a realidade da modernidade devemos ampliar consideravelmente nossos horizontes geográficos". Ora, na medida em que "a modernidade torna-se global, o mesmo deve ocorrer com a sociologia da modernidade" (Schmidt, 2012:6).

Reconhecidas as suas inconfundíveis especificidades, em linhas gerais, essas três perspectivas - globalização, modernidades múltiplas e modernidade global - não consumam um rompimento definitivo com a sociologia da modernidade. Elas mais parecem demandar a adequação de suas categorias e conceitos. O espraiamento do padrão de sociabilidade moderno para além de seu "berço originário europeu" teria provocado algumas mudanças importantes no "programa original" dentre outras razões, graças à sua mescla com outras culturas, instituições e padrões de sociabilidade, mas também em virtude da crescente diversificação da experiência moderna nos confins daquelas mesmas "sociedades modelares". Daí a necessidade de ajustar ferramentas cognitivas inicialmente formuladas à luz daquele contexto. Ambições mais ousadas e radicais, no entanto, podem ser encontradas na produção em torno da condição pós-colonial, assim como no projeto da decolonialidade do saber/poder. Nesses casos, alude-se a contraevidências empíricas que impõem desafios mais substantivos a pressupostos-chave daquele discurso. No limite, almeja-se nada menos que a elaboração de um novo quadro epistemológico.

Críticas são feitas, em primeiro lugar, ao universalismo (tido por enviesado) das categorias da sociologia da modernidade. Nesse sentido, 
Chakrabarty (2000) chama atenção para as inadequações de conceitos caros ao imaginário da modernidade política europeia - tais quais sociedade civil, direitos humanos, cidadania, igualdade perante a lei, Estado, entre outros - "em países fora das democracias capitalistas ocidentais". Na medida em que suas esferas políticas são habitadas por segmentos da população - não raro grupos subalternos - e padrões comportamentais estranhos a tal imaginário, essas sociedades seriam com alguma frequência posicionadas como se estivessem a meio caminho da modernidade. Afirma-se que exercícios de classificação dessa natureza tornam evidente a noção de temporalidade que subjaz as narrativas modernas, bem como os dispositivos discursivos empregados (dentre eles "alguma versão de uma teoria etapista da história") para obliterar seu próprio provincianismo. Para esses críticos, é sugestivo que o mesmo historicismo que dispôs a modernidade ao longo de uma estrutura temporal global e linear também "capacitou a Europa a dominar o mundo no século XIX" (Chakrabarty, 2000). Ao conceber a modernidade, o capitalismo e o iluminismo como eventos internos à sua história, a Europa renega a contemporaneidade de cenários não ocidentais, aludindo aos pretensos anacronismos e aos lapsos culturais e institucionais que distinguiriam o Ocidente de "outros lugares". Com isso, experiências não europeias e não ocidentais são invariavelmente alocadas em posições assimétricas nessa estrutura temporal global, fato que as torna alvo imediato de prescrições civilizadoras (idem).

Mas note-se que as críticas não se restringem a sublinhar a persistência de diferenças entre a Europa e o resto do mundo. Conforme argumenta Chatterjee, "há, de fato, amplos setores da sociedade ocidental contemporânea que não são necessariamente parte da entidade histórica conhecida como Ocidente moderno" (2008:57). Ou seja, trata-se também de indicar a existência de desacertos desse discurso hegemônico com respeito a seu referente privilegiado: o Ocidente (ou mais especificamente, a Europa). Nesse espírito, ao referir-se aos "limites epistemológicos" de certas "idéias etnocêntricas", Homi Bhabha indica a existência de "fronteiras enunciativas de uma gama de outras vozes e histórias dissonantes, até dissidentes" (2010: 24), dentre as quais as das "mulheres, colonizados, grupos minoritários". Tomá-las seriamente em consideração conduz-nos a suspender as imagens de homogeneidade cultural nacional que obscurecem experiências "descontínuas ou em desacordo" com a modernidade, "resistentes a suas opressivas tecnologias assimilacionistas" (ibidem:26). Ora, tais "culturas de contra-modernidade pós-colonial" podem, na visão do autor, "reinscrever o 
imaginário social tanto da metrópole como da modernidade" (ibidem:26, ênfase no original).

Por fim, até mesmo a narrativa da "originalidade europeia", apoiada sobre o suposto de um tempo linear-progressivo, coerente e homogêneo, é alvo de questionamentos (Chatterjee, 2008). Nos dizeres de Stuart Hall,

o "pós-colonial" provoca uma interrupção crítica na grande narrativa historiográfica que, na historiografia liberal e na sociologia histórica weberiana, assim como nas tradições dominantes do marxismo ocidental, reservou a essa dimensão global uma presença subordinada em uma história que poderia ser contada a partir do interior de seus parâmetros europeus" (2011:106).

Daí o chamado ao abandono de analogias espaciais - "centro/periferia", "dentro/fora" - que induzem as ciências sociais a vincular identidades, referências cognitivas, normativas e estéticas, além de formas de sociabilidade, de maneira exclusiva a certos territórios e segmentos da população.

Não menos radical é o confronto do chamado projeto da decolonialidade do saber/poder com o discurso da modernidade. A linearidade temporal subjacente àquele discurso é igualmente denunciada como artificial e perniciosa em seus efeitos: espécie de "invento ideológico" e "manipulação conceitual" ex post facto, essa concatenação histórica de eventos desconexos resulta na elevação da Europa à posição de realização suprema e culminante de desenvolvimentos na verdade dispersos (Dussel, 2005; Quijano, 2005). Some-se a isso a denúncia aos paradoxos e contradições da modernidade ocultados da narrativa oficial: se é que existe um núcleo racional (com destaque para as conquistas iluministas), haveria também uma faceta irracional com frequência obliterada (embora igualmente constitutiva), caracterizada pela dominação, violência, sofrimento e exploração. Afirma-se que em decorrência da autoproclamada superioridade da modernidade europeia, essa outra faceta é muitas vezes justificada como um custo inevitável dos benefícios da civilização; destarte, os efeitos perversos de intervenções com vistas a educar e civilizar os primitivos, bárbaros e atrasados acabam moralmente legitimadas (Escobar, 1995; Dussel, 2005). Ambiciona-se, na mesma medida, descentrar a narrativa histórica da contemporaneidade por meio da consideração de outros lugares de enunciação e agência: a despeito de localizados nas periferias/bordas, afirma-se 
que esses "Outros" foram peças-chave da própria experiência hegemônica europeia. Nesse sentido, acredita-se que o reconhecimento do protagonismo da experiência colonial na construção do quadro social contemporâneo ajudará a diluir a imagem autogeradora e autossuficiente da "modernidade" e de suas instituições (Coronil, 2005:111-112; Quijano, 2005:239).

A partir dessas críticas, anuncia-se a necessidade de uma "mudança na geopolítica do conhecimento" em detrimento da episteme moderna ou, como quer Mignolo (2005), da "perspectiva da modernidade", cuja localização geo-histórica europeia se chocaria com sua reivindicação de universalidade. Essa mudança, denominada "virada/giro decolonial", envolveria colocar em seu lugar uma "perspectiva da colonialidade", desde o princípio descentrada em "histórias locais críticas", isto é, em novos loci de enunciação de onde emergiriam formas contra-hegemônicas de conhecimento e compreensão do mundo (por exemplo, a partir de condições fronteiriças), ou ainda "formas subalternas de racionalidade", para além das "grandes narrativas do Ocidente" (Mignolo, 2000:86). Essa "perspectiva da colonialidade" é concebida como "a contrapartida silenciada e não-reconhecida da modernidade". É justamente a partir das "condições da 'ferida colonial', do sentimento de inferioridade imposto sobre seres humanos que não se encaixam no modelo predeterminado nas narrativas Euro-americanas" (Mignolo, 2005:XII) que esse novo "paradigma de conhecimento decolonial" ascenderia. E na medida em que a violência econômica (apropriação da terra, expropriação do trabalho, controle financeiro), a violência política (controle de autoridade) e a violência civil (controle de gênero e sexualidade), todas elas tidas por constitutivas da matriz colonial, sempre estiveram associadas à violência epistêmica (controle do conhecimento e da subjetividade), o "giro decolonial" desabonaria categorias, noções e conceitos hegemônicos em benefício de novas maneiras de codificar e imaginar o mundo (Mignolo, 2005).

Por certo, há diferenças indisfarçáveis entre as abordagens da póscolonialidade e da decolonialidade do saber/poder, de um lado, e o diálogo que as perspectivas anteriormente salientadas pretendem estabelecer com o discurso sociológico da modernidade; aos esforços de acomodação e ajuste dessas últimas contrasta o tom de ruptura daquelas. Reconhecidas essas especificidades, interessa-me o fato de analistas recentes sugerirem a possibilidade de se encontrar o teor de muitas dessas ponderações e críticas na vasta e polissêmica produção do pensamento 
brasileiro (Bastos, 2011; Maia, 2009; Ribeiro, 2011). Na seção seguinte, pretendo retomar um dos problemas anunciados no início do artigo: como é que a tese da singularidade brasileira se posta diante dos desafios àquele discurso da modernidade lançados por essas elaborações teóricas contemporâneas?

\section{INTERPRETAÇÕES DO BRASIL A CONTRAPELO DOS "MODELOS ESTRANGEIROS"}

Em que medida a adesão à tese da singularidade brasileira por nossos mais célebres intérpretes amarrou-os de maneira inelutável àquele discurso da experiência moderna? Haveria algum indício de que tais intérpretes almejaram e, de fato, lograram lançar seus olhares para além desse quadro de referência hegemônico? Certa feita, Brandão (2007) sugeriu que nossa posição periférica poderia proporcionar um olhar "da cultura, do capitalismo e da política mundiais" a partir de um "ângulo inusitado". Não era sua intenção celebrar sem mais a pretensa originalidade brasileira ou latino-americana. Ao contrário, Brandão manifestava-se desconfortável com a noção do Brasil como uma "singularidade auto-referente", tanto quanto com "percepções e modos de ver que tendem a comungar do suposto 'excepcionalismo' do País" (ibidem:144). Não obstante, esta continuava a parecer-lhe uma sociedade diversa das modelares, "produto da aventura européia no trópico" (ibidem:143), o que inclusive se traduziria em uma vida intelectual também marcada por especificidades.

Em verdade, essas ambiguidades são ilustrativas de algo bastante disseminado entre nossos mais admirados intelectuais; conforme tenho argumentado, não foram raros os momentos em que a imagem "não modelar" do Brasil fez-se acompanhar do sentimento de inadequação de "categorias estrangeiras" para descrever essa sociedade. Ao lado disso, contudo, foram poucas as ocasiões em que nossos intérpretes colocaram-se de maneira deliberada e sistemática a tarefa de transpor termos e noções centrais da chamada "perspectiva da modernidade". Feita essa ressalva, ainda assim não me parece um exagero afirmar que, ao trazerem à luz esses descompassos, essas disjunções entre "realidade" e "teoria", tais interpretações tocaram em questões caras ao debate sociológico contemporâneo.

Eis o argumento que quero avançar: diante do sentimento de desencaixe dessa sociedade em relação aos quadros de referência conceitual 
hegemônicos, nossos intérpretes tenderam a apontar para duas direções. Por um lado, ao reafirmarem a peculiaridade da experiência brasileira em contraste com as "sociedades centrais", tenderam a fortalecer as profecias autorrealizadoras do discurso da modernidade. Mas, por outro lado, à medida que as pretensas qualidades excepcionais de nossa sociedade eram trazidas à luz, expunham-se também os próprios limites e inadequações das noções, conceitos e parâmetros a partir dos quais esse imaginário sociológico ambicionava descrever e codificar as inúmeras e variadas experiências societais contemporâneas.

Portanto, o fato de nossos intérpretes ocuparem um lugar de enunciação não hegemônico no quadro da modernidade teve ao menos dois efeitos importantes em sua relação com o discurso sociológico da experiência moderna. De um lado, essa posição com alguma frequência favoreceu o reforço da imagem da brasileira como uma configuração diversa e, no limite, original em relação aos cenários modelares (justamente aqueles que ocupavam lugares hegemônicos de enunciação). Não por acaso, os retratos construídos para dar visibilidade a nossa alardeada singularidade comumente expressaram sentimentos de falta, de insuficiência, de disjunção ou mesmo de "incompletude" em referência a cenários por sua vez assumidos como plenos, autênticos, coesos, internamente articulados e completos em inúmeros aspectos (culturais, políticos, econômicos, subjetivos, estéticos, epistêmicos, normativos, institucionais etc.). De outro lado, contudo, essa mesma posição não hegemônica abriu-lhes a possibilidade de vislumbrar e interpelar a modernidade a partir de perspectivas que iluminaram aspectos e dimensões da experiência moderna nem sempre capturados, quando não ocultados, pelas narrativas hegemônicas. A meu ver, é precisamente nessas ocasiões que se anuncia a promessa de crítica da tese da singularidade brasileira. Esse não foi um encadeamento necessário, comum a todas as empreitadas interpretativas. No entanto, quando essas articulações estiveram presentes e atuantes para além das supostas "incompletudes", faltas e insuficiências da experiência moderna no Brasil, vinham também às claras as fragilidades daquele discurso, suas disjunções e descompassos em relação aos próprios cenários societais tomados por modelares.

Que fique bem claro: não se trata de dizer que o pensamento social brasileiro tenha inadvertidamente tocado em "categorias residuais" do discurso sociológico da modernidade, apenas hoje integralmente recuperadas por seus críticos mais argutos e perspicazes. De outro modo, 
parece-me que ao versar sobre uma realidade classificada como "não modelar" - segundo os parâmetros e referenciais desse discurso - tal pensamento trouxe à luz aspectos da própria "realidade modelar" que escaparam ao campo de visão daquele quadro de referência hegemônico. Nessas ocasiões, é possível identificar algumas convergências entre, de um lado, as obras e esforços de compreensão da formação e experiência social brasileiras e, de outro, os desafios ao discurso sociológico da modernidade aludidos há pouco. Dentre as fragilidades sugeridas nos dois casos, destaco as seguintes: o historicismo sobre o qual descansa esse discurso; o nacionalismo metodológico que de maneira mais ou menos sutil subjaz esse quadro de referência; o escopo de aplicação pretendido para suas principais categorias e noções, bem como as insinuações prescritivas projetadas sobre situações e cenários tidos como "desconexos" ou "incompletos"; os próprios termos constitutivos da grade conceitual desse discurso, tomados como referência para se aferir os sucessos e insucessos de diversas experiências modernas. Por fim, apesar de poucas, há também ocasiões em que se anuncia a necessidade de transposição do quadro de referência da "perspectiva hegemônica da modernidade" como condição sine qua non à compreensão adequada da pretensa "singularidade brasileira".

Nesse exato sentido, várias dessas avaliações chamaram atenção para dinâmicas, transformações e desenvolvimentos caros à formação brasileira cujos contornos temporais mostravam-se bem mais complexos e resistentes à concepção progressivo-linear do imaginário da modernidade. Em segundo, seguidas ênfases nas interconexões (históricas, políticas, culturais, econômicas, institucionais etc.) de nossa formação social com outras regiões e contextos sugeriam a insuficiência da sociedade nacional como unidade de análise primordial. Em terceiro lugar, tais análises indicaram de maneira contundente a inadequação da estrutura conceitual empregada para se aferir o grau de modernidade de experiências sociais diversas, bem como de modelos institucionais tidos por estrangeiros a essas realidades não modelares. Finalmente, em situações-limite, a própria validade científica desse discurso era colocada sob suspeita.

Para iniciar, guardadas as suas irredutíveis especificidades, em vários esforços de interpretação do Brasil é patente o desconforto em relação à concepção temporal sobre a qual se sustentam as mais influentes narrativas sociológicas da experiência moderna. Freyre, por exemplo, fala-nos de uma "noção hispânica de tempo", distinta da temporalidade cronológica e progressiva associada à "experiência norte-euro- 
peia". Essa concepção diferiria do "ritmo constantemente progressivo" - "como o tempo europeu se tornou desde o princípio da Revolução Comercial" - em favor de uma noção marcada pela "fusão de passado, presente e futuro" (Freyre, 1975:8-9). Florestan Fernandes (1975:52-53), por sua vez, sugere haver entre nós a coexistência de temporalidades distintas - arcaicas e modernas -, ou ainda, de "várias épocas histórico-econômicas distintas (mas coetâneas)" em virtude do que "estruturas econômicas em diferentes estágios de desenvolvimento" são "combinadas organicamente e articuladas no sistema econômico global" (Fernandes, 1976:268-269).

Em segundo lugar, ponderações em relação aos próprios termos e categorias-chave do "discurso sociológico da modernidade", bem como às reais possibilidades de sua aplicação ao caso brasileiro, podem ser igualmente encontradas em nossas mais celebradas obras e esforços interpretativos. Parece ser este o caso das dissonâncias comumente apontadas entre a configuração emocional associada à experiência moderna e aquela que nossos intérpretes afirmam persistir no Brasil. Num extremo, alude-se à existência de hiatos de natureza psicodinâmica que teriam dificultado sobremaneira a plena integração de certos segmentos marginalizados à ordem social racional-competitiva (Fernandes, 2008). Mas, de maneira mais generalizada, abundam referências ao personalismo exacerbado do brasileiro, responsável por vinculá-lo de modo determinante a laços afetivos primários, os quais moldariam expectativas e padrões de comportamento incongruentes com os códigos e imperativos próprios de uma ordem impessoal (Holanda, 1994; Torres, 1982; DaMatta, 1997). A isso se soma a imagem desta como uma sociedade não plenamente racionalizada, permeada por referências normativas tradicionais agindo sobre âmbitos públicos e privados (Freyre, 2000; Holanda, 1994).

Também conforme indiquei anteriormente, o suposto moderno da separação entre domínios públicos e âmbitos privados com frequência encontrou dificuldade análoga para ajustar-se às interpretações do Brasil. Seja em virtude de nossas heranças patriarcais (Freyre, 2000; Vianna, 1987), seja em razão de vícios patrimonialistas duradouros (Faoro, 2001), ou mesmo da resiliência de relações de produção dadas por extintas nas ditas "sociedades centrais" (Prado Jr., 2008, 2011; Fernandes, 1976), é perene a ideia de que, entre nós, interesses privados continuam a projetar-se e a moldar indevidamente espaços públicos de sociabilidade (Vianna, 1987; Holanda, 1994). Na mesma medi- 
da, fala-se do caráter incompleto dos processos de diferenciação e complexificação sociais no Brasil. Disso decorreriam a confusão, a sobreposição e o choque de atribuições que, em cenários plenamente modernos, seriam exclusivos a âmbitos sociais específicos (Estado, mercado, sociedade civil, família, esfera pública etc.). Sinal de atraso, esse quadro de quase ou semidiferenciação seria impeditivo à constituição autônoma e autorreferente de cada uma dessas esferas, redundando em prejuízo generalizado de eficiência funcional (Cardoso, 1972; Faoro, 2001; Fernandes, 1975; DaMatta, 1997).

Nem mesmo o suposto da separação entre a sociedade e a natureza escapa às reflexões de nossos intérpretes. Vale salientar que a própria construção da identidade nacional brasileira a partir do século XIX quase sempre esteve de alguma maneira vinculada aos atributos naturais do território (Ventura, 1991). Em muitas ocasiões, o ambiente tropical foi responsabilizado por moldar o caráter nacional com traços que destoavam dos requisitos da civilização moderna (Cunha, 1981; Romero, 1949). Em outras oportunidades, essa mesma natureza foi cantada e celebrada por nos legar qualidades e vantagens inéditas em relação a outras sociedades (Freyre, 2000). Seja como for, o pontochave é que vários esforços de interpretação atribuíram à natureza peso condicionante, quando não posição protagonista nos processos de formação e vivência de referências modernas pela sociedade brasileira.

Finalmente, há que se reconhecer a existência de formulações mais ou menos ousadas no seio do pensamento social brasileiro que apontam para a necessidade de superação de termos e noções caras à "perspectiva da modernidade" como condição sine qua non à compreensão de nossa experiência. Assim é que Bomfim denunciava os "doutores e publicistas da política mundial [que] se limitam a lavrar sentenças - invariáveis e condenatórias" às sociedades latino-americanas (1993:38). Sua insatisfação com certos "juízos categóricos", sustentados pelo que qualificava como disparates conceituais e apreciações absurdas (ibidem:40), traduziu-se em sua crítica à teoria da inferioridade das raças por meio da qual os europeus explicavam sua pretensa superioridade em relação às populações latino-americanas. Para ele, "tal teoria não passa de um sofisma abjeto do egoísmo humano, hipocritamente mascarado de ciência barata, e covardemente aplicado à exploração dos fracos pelos fortes" (ibidem:243).

Em outro momento e com outra visada, Freyre lamentava os efeitos perniciosos decorrentes do fato de que 
quase todas as interpretações atuais do que seja a civilização européia mesmo a russa ou a ibérica - em face das não européias, têm sido elaboradas por antropólogos, sociólogos, historiadores e sobretudo, pensadores, cujas personalidades se desenvolveram dentro de circunstâncias, se não sociais, de cultura ou de disciplina intelectual, peculiares à Europa mais especificamente européia (Freyre, 2010:294).

Num breve ensaio publicado originalmente em 1950, Freyre ousou argumentar que "Não deveria haver ciência social 'nacional', como se fosse alguma coisa oposta à ciência social supranacional" (2003:57). Manifestava, assim, seu receio quanto aos excessos de "interesses e aspirações nacionalísticos" que se insinuavam na sociologia com prejuízo das possibilidades de "compreensão universal". Isso não implicava sua total rejeição às "projeções nacionais", mas sim ao que qualificava como "distorções nacionalísticas". Uma dessas "distorções" seria a construção e projeção de estereótipos sobre "grupos híbridos, etnicamente compostos por uma mistura de europeus com as chamadas raças inferiores", sugerindo que "esses povos fossem destinados pela natureza ou pelo pecado - o 'pecado da miscigenação' - a serem colônias de 'povos superiores' ou, quando independentes, simples subnações" (ibidem:62). O problema, a seu ver, era que os efeitos perniciosos desse viés nacionalista não se esgotavam nesse ponto: os próprios grupos estereotipados ("latino-americanos, asiáticos e africanos", povos híbridos "localizados em zonas tropicais, ou quase tropicais") acabavam por construir autoimagens também pessimistas, em conformidade com ideias condenatórias, que sacramentavam sua condição de inferioridade em relação a tais "povos superiores". Freyre não queria, com isso, desconsiderar a existência de traços peculiares a cenários específicos. Não obstante, parecia-lhe fundamental encurtar distâncias teórico-interpretativas que de maneira artificial estabeleciam um divórcio intransponível entre experiências sociais e regiões do globo variadas.

Por sua vez, Guerreiro Ramos (1996:68) recusou a “assimilação literal e passiva dos produtos científicos importados" - isto é, do "patrimônio científico estrangeiro" - e advogou em favor de uma "sociologia autêntica", ajustada às especificidades dos contextos nacionais diversos. Anos depois, Florestan Fernandes afirmaria que "é ponto pacífico que os recursos conceptuais, metodológicos e teóricos da Sociologia foram construídos através da observação, análise e interpretação de alguns países da Europa e dos EUA". Ora, segundo o autor, "O chamado mundo subdesenvolvido não só apresenta uma enorme variedade de situa- 
ções histórico-sociais distintas, que contrastam com a desses países, como dificilmente se poderiam explorar frutiferamente aqueles recursos (...) sem uma criteriosa adequação deles (...)" (Fernandes, 1975:17-18).

Conforme salientei anteriormente, esses desencontros entre os intérpretes do Brasil e o "discurso sociológico hegemônico da modernidade" a princípio poderiam ser tomados exclusivamente como evidência e confirmação da "incompletude" da sociedade brasileira em relação aos cenários e contextos tidos por modelares da experiência moderna. No entanto, revisitados à luz dos debates contemporâneos, esses mesmos descompassos podem também ser percebidos como desafios que lugares de enunciação não hegemônicos suscitam àquele discurso, flagrando-o em seus próprios limites e fragilidades: em virtude de sua posição marginal, ao versar sobre a pretensa "singularidade brasilei$\mathrm{ra}^{\prime}$, tais olhares iluminaram aspectos e facetas da experiência moderna, amplamente considerada, negligenciados pela "perspectiva da modernidade". Nessa visada, as distâncias entre esses parâmetros hegemônicos e contextos não hegemônicos podem talvez ser tomados como índices dos desacertos e lapsos entre aquele discurso e seus referentes preferenciais, as ditas "sociedades centrais".

\section{A EXPERIÊNCIA BRASILEIRA AQUÉM E ALÉM DO NACIONALISMO METODOLÓGICO}

Em situações-limite, a tese da singularidade brasileira chega a reivindicar noções, conceitos, teorias e ferramentas metodológicas especiais, adequados à pretensa irredutibilidade dessa experiência. Nessa exata direção, vemos Guerreiro Ramos defender que enquanto

No plano geral do raciocínio sociológico, as "normas", "valores" e "ideais" transcendem as particularidades históricas de cada sociedade nacional, [continua ele], No terreno concreto, porém, a utilização prática do saber sociológico obedece, em cada sociedade nacional, a "normas", "valores" e "ideais" específicos, que refletem a particularidade histórica de sua situação (Ramos, 1996:23-24).

Ora, aceita a existência de "uma perspectiva brasileira", como não transferir ao cientista o desafio e "a tarefa de fundação de uma sociologia nacional" (ibidem:41-42)? Bem sabemos que, a certa altura, esse foi um ponto de tensão entre o próprio autor e Florestan Fernandes; acusado por Guerreiro Ramos de provinciano e "hiper-correto", Florestan 
teria se deixado seduzir pelo universalismo enviesado dos "cânones estrangeiros". Ainda que o extremismo do autor de A Redução Sociológica encontre poucos símiles, a tendência para enxergar traços inconfundíveis e específicos da experiência brasileira - conforme analisei anteriormente -é algo bastante disseminado em nosso pensamento social.

Em verdade, Roberto Schwarz já teve oportunidade de visitar essa questão, atentando-nos para uma das reações extremas ao "sentimento da contradição entre a realidade nacional e o prestígio ideológico dos países que nos servem de modelo", qual seja, "a busca de um fundo nacional genuíno, isto é, não adulterado", ou mesmo, de uma "substância autêntica do país" (2009b:109-115). A meu ver, é sugestivo que a busca dessa pretensa essência nacional seja frequentemente informada pelas mesmas lentes acusadas de postiças em relação a essa realidade; por meio delas, os traços da alardeada peculiaridade brasileira sobressaem-se em contraste com o "centro", o que, de quebra, confirma a posição modelar deste.

Por um lado, o próprio esforço de Schwarz, ao associar características tidas por peculiares à sociedade brasileira à sua posição periférica no cenário capitalista mundial, pode ser visto como um exercício de ruptura de certo nacionalismo metodológico. Mas, conforme sugerem as reflexões de Franco (1976), nem sempre tal mudança de perspectiva resultou no abandono daquele pressuposto que estabelece uma ordem de sucessão entre o "centro" e a "periferia" em razão de suas alardeadas "diferenças essenciais" "rompimento conceitual com o primado da origem" uma solução convincente para "equacionar ou combater relações de subordinação efetiva". Na realidade, para ele, a "fatalidade da imitação cultural se prende a um conjunto particular de constrangimentos históricos" (2009b:119).

Como venho observando, sua avaliação não é consensual. Além das já mencionadas reações de Franco (1976) e Bosi (1995), Rouanet rebateu a proposta de Schwarz afirmando que "há um enorme exagero na tese do desajuste entre idéias externas e realidade brasileira". A seu ver, "Em muitos casos não houve desajuste nenhum, mas uma perfeita congruência" (Rouanet, 1994:36). Daí tratar-se, em seu entendimento, de "uma questão secundária", caudatária do "topos da autenticidade cultural". Mas é um outro ponto avançado por Rouanet que gostaria de 
destacar: o autor nos fala da vulnerabilidade das premissas da "tese nacionalista", apoiadas sobre "uma ideologia historista implícita, de origem herderiana"; a seu ver, tais premissas desconsideram o incontornável desenraizamento observado em toda e qualquer cultura. Fato é que, em seu entendimento, a mesma Europa exportadora de modelos de organização social importou de países não europeus inúmeros "arquétipos" que contribuíram para "alimentar seu imaginário" e suas fantasias de superioridade (Rouanet, 1994:39-40).

Este parece-me o ponto-chave: exercícios de compreensão da experiência societal brasileira que ambicionem estabelecer um diálogo crítico com a sociologia da modernidade demandam do analista abrir mão da experiência nacional como uma categoria analítica inequívoca. Mutatis mutandis, uma análise da tese da singularidade brasileira atenta à sua tendência de emoldurar ex ante o real envolve duas tarefas: a) confrontar o nacionalismo metodológico que implícita ou explicitamente perpassa tanto a sociologia da modernidade como o pensamento social brasileiro; b) orientar o olhar preferencialmente para as conexões e entrelaçamentos envolvendo experiências societais diversas (em seus diferentes níveis).

É verdade que tais conexões e entrelaçamentos não são de modo algum estranhos a vários de nossos intérpretes. Talvez se possa dizer que justamente sua posição não hegemônica de enunciação - com frequência assombrados pelo peso de nossa suposta "inautenticidade" - tenha-os incentivado a contemplar as conexões da formação brasileira com outros contextos e cenários societais. Ao atentarem para os circuitos extranacionais de bens econômicos e simbólicos, de modelos políticos e institucionais, além das referências cognitivas, normativas e estéticas em meio aos quais essa sociedade ganhou existência, tais intérpretes sugeriram a necessidade de abordar suas alardeadas "singularidades" para além delas mesmas (Romero, 1949; Bomfim, 1993; Holanda, 1994; Freyre, 2000; Furtado, 2009; Prado Jr., 2011; Fernandes, 1976, para nos restringirmos a poucos exemplos). No entanto, por mais sofisticadas e cuidadosas que tenham sido, ainda assim tais sugestões não tiveram o efeito de desmontar por completo o nacionalismo metodológico que as orientava - dentre outras razões porque este não era o efeito pretendido. De outro modo, quando contemplaram aquelas conexões, o fizeram para salientar as sínteses peculiares que teriam desaguado naquilo que nos tornamos ${ }^{9}$. 
Mas é claro que essa tendência não lhes é exclusiva. Conforme tem-se argumentado, "As estruturas epistêmicas e os programas das ciências sociais mainstream têm permanecido fortemente atrelados ao, e moldados pela experiência da formação do estado-moderno" (Wimmer e Schiller, 2002:303; tradução livre). Por esse motivo, não é de estranhar que o Estado-nação seja tratado como "a representação natural e necessária da sociedade moderna" (Chernilo, 2011:99; tradução livre). Por certo, seria no mínimo pueril desconsiderá-lo como "uma forma moderna de arranjo sócio-político". Mas isso é muito diferente de "ver a modernidade como o resultado final de um número de desenvolvimentos nacionais diferentes e endógenos" (ibidem:109; tradução livre). Ora, a adoção da sociedade brasileira como categoria analítica - sob a alegação de que somente assim consegue-se captar inconfundíveis singularidades - tem, com frequência, redundado na confirmação de uma episteme desatenta às incongruências e descompassos dos próprios "contextos modelares da modernidade".

Foge aos propósitos precípuos deste artigo elaborar uma receita analítica acabada para esses dilemas. À guisa de conclusão, desejo ao menos lançar o seguinte argumento: a saída dessa armadilha envolve considerar enfaticamente as conexões simbólicas, epistêmicas, econômicas, culturais, institucionais, econômicas etc. que de um ponto de vista histórico revelaram-se fundamentais à formação e experiência societais brasileiras. Conforme Sanjay Subrahmanyam já teve oportunidade de argumentar, caso se queira contornar os "essencialismos" que comumente acompanham "unidades geográficas convencionais de análises", é preciso substituir a perspectiva metodológica das "histórias comparadas" pela perspectiva das "histórias conectadas" (1997:742-743). Essa escolha capacita-nos a apreender as tramas e nexos que entrelaçam os destinos de localidades e regiões diversas (inconfundíveis com recortes nacionais), aproximando cenários equivocadamente retratados como "zonas culturais fechadas", como se estes fossem dotados de histórias autônomas.

Mesmo esta opção pelas histórias conectadas tem implicações analíticas distintas conforme a direção conferida ao olhar. Uma vez mais, volto a indicar algumas possibilidades de encaminhamento analítico. Se, ao se contemplar tais conexões, a ênfase recair sobre a consideração dos desdobramentos históricos peculiares advindos desses entrelaçamentos, o resultado provável estará mais próximo da crítica ao discurso sociológico elaborada pela abordagem das modernidades múltiplas. Nesse 
caso, a experiência brasileira poderá ser codificada como um tipo singular e irredutível de modernidade (a modernidade brasileira); em uma hipótese mais promissora, poderá ser tomada como partícipe de uma classe mais ampla de sociedades, unidas por aspectos também inconfundíveis no quadro da modernidade (um tipo de modernidade periférica, de modernidade semiperiférica, ou ainda um exemplar da modernidade latino-americana).

De outro modo, caso a ênfase da consideração de tais conexões recaia sobre efeitos e desdobramentos compartilhados (uma vez mais, sejam eles institucionais, simbólicos, econômicos, epistêmicos, culturais, dentre outros), o resultado da análise se aproximará das críticas desferidas pela abordagem da modernidade global. Há, aqui, ao menos duas possibilidades diversas: pode-se tomar a modernidade como uma experiência descentrada desde seus primórdios, isto é, "uma virada mais ou menos global, com muitas fontes e raízes diferentes" (Subrahmanyam, 1997), resultante de desenvolvimentos partilhados por localidades e regiões distintas; nesse caso, haveria fluxos de bens materiais, bem como de "idéias e construções mentais" que desde os passos iniciais em direção à experiência moderna atravessaram fronteiras diversas e que contribuíram para o estabelecimento de redes e processos de circulação extranacionais (ibidem). De outro modo, pode-se tomar a modernidade como um evento que, apesar de europeu em suas origens, a partir de um determinado momento projetou-se para inúmeras regiões, unificando referências institucionais, simbólicas, cognitivas etc. nos quatro cantos do mundo. Na esteira desses desenvolvimentos, localidades e regiões outrora receptoras teriam tornado-se elas próprias centros difusores de padrões e instituições, aprofundando o programa da modernidade e, ao mesmo tempo, diversificando as modalidades de suas manifestações.

Por fim, a consideração desses laços e conexões poderá conferir atenção aos efeitos discursivos de poder advindos de processos de formação e estabilização de centros de hegemonia global. Na direção sugerida pelas críticas pós-colonial e decolonial, pode-se querer interpelar a consolidação de estruturas epistêmicas assimétricas que fazem da experiência de segmentos específicos da sociedade europeia padrões de medida a partir dos quais outras experiências (dentro ou fora dos confins da Europa) são codificadas ao mesmo tempo que hierarquicamente dispostas. Nesse caso, ao invés de tomá-la como uma configuração societal única e especial em comparação com outros cenários sócio- 
históricos (do passado e do presente), trata-se de abordar a modernidade prioritariamente como uma retórica, ou ainda, como uma perspectiva discursiva que, ancorada em posições hegemônicas de enunciação, perpetua relações assimétricas de poder econômico, cultural, epistêmico, simbólico, político etc. São os efeitos dessa retórica sobre regiões e segmentos não europeus da população, ao lado das facetas obscurecidas dessa experiência, que migram para o centro da agenda de análise e reflexão.

Importa salientar que, independentemente da ênfase conferida, todas as três modalidades de análise convidam-nos a vislumbrar o discurso sociológico da modernidade para além e aquém de contextos nacionais específicos. Ainda que pensados apenas e tão somente como elementos de uma perspectiva discursiva, diferenciação/complexificação social, secularização, separação público/privado, experiência subjetivo-emocional centralizada, e disjunção sociedade/natureza deixam de ser associados exclusivamente às experiências de sociedades nacionais, tanto em suas origens como em seus desenvolvimentos posteriores. Da mesma forma, referências cognitivas, simbólicas, institucionais, normativas, estéticas e políticas caras ao imaginário e à organização societal contemporâneos podem ser contemplados com maior atenção às relações que aproximam e distanciam segmentos sociais de diferentes localidades, regiões e nações do mundo. Seja qual for a escolha, é cada vez mais problemático continuar a sustentar a existência de predicados brasileiros singulares, irredutíveis e inconfundíveis com outras sociedades contemporâneas.

(Recebido para publicação em outubro de 2013)

(Reapresentado em março de 2014)

(Aprovado para publicação em abril de 2014) 


\section{NOTAS}

1. Essa obsessão pela "peculiaridade" não é algo singular ao pensamento brasileiro. Trata-se de um exercício que acompanha processos de formação nacional em outras tantas experiências societais. Isso posto, o artigo pode ser lido como uma análise crítica de algumas tentativas de codificação da pretensa "singularidade brasileira".

2. Uma apreciação recente dos termos e preocupações centrais desse discurso sociológico hegemônico da modernidade pode ser encontrada em Eisenstadt (2010), em sua crítica às premissas das teorias da modernização, segundo ele observáveis também nas principais análises sociológicas clássicas (Marx, Weber e Durkheim). À luz dessas discussões, sugiro que tal "discurso hegemônico" retrata e distingue o padrão de sociabilidade frente a outros com base em cinco aspectos fundamentais: a) diferenciação/complexificação social; b) secularização societal; c) economia emocional ancorada na "subjetividade centrada/indivisível"; d) disjunção entre público e privado; e) separação entre sociedade e natureza. De maneiras mais ou menos explícitas, esses aspectos são assumidos como padrões de medida por meio dos quais afere-se e infere-se o status da modernidade de configurações e experiências societais concretas.

3. É indispensável recordar a reação de Carvalho Franco em "As Idéias Estão no Lugar", no qual a autora rechaça "o pressuposto de uma diferença essencial entre nações metropolitanas, sede do capitalismo, núcleo hegemônico do sistema, e os povos coloniais, subdesenvolvidos, periféricos e dependentes"; segundo a autora, em virtude desse pressuposto, "se estabelece uma relação de exterioridade entre os dois termos em oposição", ou seja, "uma relação de causalidade" que se traduz em "uma ordem de sucessão" entre o centro e a periferia (Franco, 1976:61). Note-se que, embora aponte como solução para o problema considerar ambos os contextos nos marcos do "processo interno de diferenciação do sistema capitalista mundial", Maria Sylvia não abandona a ideia de que os dois termos do par ("colônia e metrópole") consistem em "situações particulares", cada qual fruto de "desenvolvimentos particulares" (ibidem: 62). São igualmente ilustrativas as reflexões e esclarecimentos mais recentes de Schwarcz acerca daquele debate (Schwarcz e Botelho, 2008).

4. Caso observado, por exemplo, em História da Literatura Brasileira (1949 [1888]), de Silvio Romero.

5. A título de ilustração, enquanto, para Freyre (2000), o encontro e a mistura racial e cultural entre o negro africano, o português e o ameríndio resultaram em algo verdadeiramente singular e sem precedentes, na visão de Holanda (1994:11), de Portugal "nos veio a forma atual de nossa cultura; o resto foi matéria que se sujeitou mal ou bem a essa forma". Malgrado a existência dessas diferentes posições acerca das rupturas e continuidades da experiência brasileira, a meu ver, ainda assim subsiste o pressuposto conforme o qual tal experiência está descompassada dos principais "modelos civilizatórios" ou, em outros termos, das "sociedades modernas centrais".

6. Ademais, tendo a endossar a avaliação de Brandão (2007:25) acerca do peso dos "clássicos" no presente: "Apesar do caráter datado de muitas de suas proposições teóricas e bases empíricas", eles continuam a ser lidos "como fontes de problemas, conceitos, hipóteses e argumentos para a investigação científica do presente" (idem).

7. Na interpretação de Schmidt (2012), esse núcleo seria composto pelos seguintes elementos: modernização da sociedade (diferenciação funcional), modernização da 
cultura (racionalização, aumento da reflexividade, generalização valorativa), modernização da pessoa (individuação, ativismo, multiplicidade de selves, aumento de capacidade cognitiva) e modernização do organismo (disciplina e aperfeiçoamento do corpo humano).

8. Ainda naquele célebre embate, Maria Sylvia argumenta que a formulação conforme a qual "O Brasil, por ser um país colonial, tem na Europa a fonte de suas ideias (...) aparece inscrita em pelo menos dois séculos de nossa história intelectual", formulação que, segundo a autora, de certa forma perdurou inclusive na teoria da dependência (Franco, 1976:61 e 63).

9. Nobre (2012) entende que os livros A Forma Difícil (de Rodrigo Naves) e O Trato dos Viventes (de Luiz Felipe de Alencastro), ambos publicados na segunda metade dos anos 1990, são expressivos de um novo momento no qual a formação da sociedade brasileira passa enfim a ser pensada, de modo mais vigoroso, para fora dela mesma. 


\section{REFERÊNCIAS BIBLIOGRÁFICAS}

ALONSO, Angela. (2002), Idéias em Movimento: A Geração 1870 na Crise do Brasil-Império. São Paulo, Paz e Terra.

BASTOS, Élide. (2011), "Atualidade do Pensamento Social Brasileiro". Sociedade e Estado, vol. 26, no 2, pp. 51-70.

BHABHA, Homi. (2010), O Local da Cultura. Belo Horizonte, Editora UFMG.

BOMFIM, Manoel. (1993) [1905], A América Latina: Males de Origem. Rio de Janeiro, Topbooks.

BOSI, Alfredo. (1995), “Origem e Função das Idéias em Contextos de Formação Colonial", in Centro de Estudos Brasileiros/Embaixada do Brasil em Roma (org.), Pensamento Brasileiro. Palermo, Renso e Rean Mazzone Editori, pp. 17-31.

BOTELHO, André. (2003), “Na Contracorrente do Naturalismo: Relações Sociais na Interpretação do Brasil de Manoel Bomfim”. Temáticas, vol. 11, nos 21/22, pp. 75-100. e SCHWARCZ, Lilia. (2009), Um Enigma Chamado Brasil: 29 Intérpretes e um País. São Paulo, Companhia das Letras.

BRANDÃO, Gildo. (2007), Linhagens do Pensamento Político Brasileiro. São Paulo, Aderaldo \& Rothschild Editores.

CARDOSO, Fernando H. (1972), O Modelo Político Brasileiro. São Paulo, Difel. . (1980), As Idéias e seu Lugar: Ensaios sobre as Teorias do Desenvolvimento. Petrópolis, Vozes/Cebrap.

. (2013), Pensadores que Inventaram o Brasil. São Paulo, Companhia das Letras.

CASTELLS, Manuel. (1999), O Poder da Identidade. São Paulo, Paz e Terra.

CHAKRABARTY, Dipesh. (2000), Provincializing Europe: Postcolonial Thought and Historical Difference. Princeton, Princeton University Press.

CHATTERJEE, Partha. (2008), La Nación en Tiempo Heterogéneo. Buenos Aires, Siglo Veinteuno.

CHERNILO, Daniel. (2011), "The Critique of Methodological Nationalism: Theory and History". Thesis Eleven, vol. 106, no 1, pp. 98-117.

CORONIL, Fernando. (2005), “Natureza do Pós-Colonialismo: Do Eurocentrismo ao Globocentrismo", in E. Lander (org.), A Colonialidade do Saber: Eurocentrismo e Ciências Sociais. Buenos Aires, Clacso, pp. 105-132.

CRUZ COSTA, João. (1964), A History of Ideas in Brazil: The Development of Philosophy in Brazil and the Evolution of National History. Berkeley, University of California Press.

CUNHA, Euclides da. (1981), Os Sertões: Campanha de Canudos. Rio de Janeiro, Francisco Alves.

DAMATTA, Roberto. (1997), A Casa \& a Rua: Espaço Cidadania, Mulher e Morte no Brasil. Rio de Janeiro, Rocco.

DIRLIK, Arif. (2003), "Global Modernity? Modernity in an Age of Global Capitalism”. European Journal of Social Theory, vol. 6, no 3, pp. 275-292. 
DOMINGUES, José M. (2009), “Global Modernization, 'Coloniality' and a Critical Sociology for Contemporary Latin America”. Theory, Culture E Society, vol. 26, no 1, pp. 112-133.

. (2003), Do Ocidente à Modernidade: Intelectuais e Mudança Social. Rio de Janeiro, Civilização Brasileira.

DUSSEL, Enrique. (2005), “Europa, Modernidade e Eurocentrismo”, in E. Lander (org.), A Colonialidade do Saber: Eurocentrismo e Ciências Sociais. Buenos Aires, Clacso, pp. 55-70.

EISENSTADT, Shmuel N. (2000), “Multiple Modernities". Daedalus, vol. 129, no 1, pp. $1-29$.

. (2010), “Modernity and Modernization". Sociopedia.isa, vol. 25, no 1, International Sociological Association, pp. 1-15.

ESCOBAR, Arturo. (1995), Encountering Development: The Making and Unmaking of the Third World. Princeton, Princeton University Press.

FAORO, Raymundo. (2001), Os Donos do Poder: Formação do Patronato Político Brasileiro. São Paulo, Editora Globo.

FERNANDES, Florestan. (1975) [1968], Sociedade de Classes e Subdesenvolvimento. Rio de Janeiro, Zahar.

. (1976) [1975], A Revolução Burguesa no Brasil: Ensaio de Interpretação Sociológica. Rio de Janeiro, Zahar.

. (2008) [1964], A Integração do Negro na Sociedade de Classes. São Paulo, Editora Globo, vol. 1 .

FOUCAULT, Michel. (1972), The Archaeology of Knowledge \& the Discourse on Language. New York, Pantheon Books.

FRANCO, Maria Sylvia C. (1976), “As Idéias Estão no Lugar”. Cadernos de Debate, no 1. São Paulo, Brasiliense, pp. 61-64.

FREYRE, Gilberto. (1975), O Brasileiro entre os Outros Hispanos: Afinidades, Contrastes e Possíveis Futuros nas suas Inter-relações. Rio de Janeiro, José Olympio/Brasília, Instituto Nacional do Livro.

. (2000) [1933], Casa-Grande E Senzala: Introdução à História da Sociedade Patriarcal no Brasil. Rio de Janeiro, Record.

. (2003), Palavras Repatriadas. Brasília, Ed. UnB/São Paulo, Imprensa Oficial do Estado.

(2010) [1960], O Luso e o Trópico. São Paulo, É Realizações.

FRIEDMAN, Jonathan. (1995), "Global System, Globalization and the Parameters of Modernity", in M. Featherstone et al. (eds.), Global Modernities. London, Sage Publications, pp. 69-90.

FURTADO, Celso. (2009) [1959], Formação Econômica do Brasil. São Paulo, Companhia das Letras.

HALL, Stuart. (2011), Da Diáspora: Identidades e Mediações Culturais. Belo Horizonte, UFMG Editora. 
HELD, David et al. (1999), Global Transformations: Politics, Economics and Culture. Stanford, Stanford University Press.

HOLANDA, Sérgio B. de. (1994) [1936], Raízes do Brasil. Rio de Janeiro, José Olympio.

IANNI, Octavio. (1992), A Idéia de Brasil Moderno. São Paulo, Brasiliense. (1996), A Era do Globalismo. Rio de Janeiro, Civilização Brasileira.

LIDKE, Enno. (2005), “A Sociologia no Brasil: História, Teorias e Desafios”. Sociologias, vol. $7, \mathrm{n}$ ㅇ 14, pp. 376-437.

MAIA, João M. (2009), "Pensamento Brasileiro e Teoria Social: Notas para uma Agenda de Pesquisa". Revista Brasileira de Ciências Sociais, vol. 24, no 71, pp. 155-168.

MIGNOLO, Walter. (2000), "(Post)Occidentalism, (Post)Coloniality, and (Post)Subaltern Rationality", in F. Afzal-khan e K. Seshadi-Crooks (eds.), The Pre-Occupation of Postcolonial Studies. Durham/London, Duke University Press, pp. 86-118.

(2005), The Idea of Latin America. Oxford, Blackwell.

NOBRE, Marcos. (2012), “Depois da 'Formação'”. Piauí, no 74, pp. 74-77.

ORTIZ, Renato. (2006), Cultura Brasileira e Identidade Nacional. São Paulo, Editora Brasiliense.

. (2009), "Globalização: Notas sobre um Debate". Sociedade e Estado, vol. 24, no 1, pp. 231-254.

PARSONS, Talcott. (1971), The System of Modern Societies. Englewood Cliffs, Prentice-Hall Inc.

PIETERSE, Jan. (1995), “Globalization as Hybridization”, in M. Featherstone et al. (eds.), Global Modernities. London, Sage, pp. 45-68.

PRADO JR., Caio. (2008) [1945], História Econômica do Brasil. São Paulo, Brasiliense.

. (2011) [1942], Formação do Brasil Contemporâneo: Colônia. São Paulo, Companhia das Letras.

QUIJANO, Aníbal. (2005), "Colonialidade do Poder, Eurocentrismo e América Latina", in E. Lander (org.), A Colonialidade do Saber: Eurocentrismo e Ciências Sociais. Buenos Aires, Clacso, pp. 227-278.

RAMOS, Alberto Guerreiro. (1996) [1958], A Redução Sociológica. Rio de Janeiro, UFRJ Editora.

RIBEIRO, Adélia. (2011), “Darcy Ribeiro e o Pensamento Crítico Latino-americano: Diálogos com a Epistemologia Pós-Colonial". Sinais - Revista Eletrônica de Ciências Sociais, vol. 1, no 9, pp. 12-31.

ROMERO, Silvio. (1949) [1888], História da Literatura Brasileira. Rio de Janeiro, Livraria José Olympio, Tomo I.

ROSTOW, Walt W. (1974), As Etapas do Desenvolvimento Econômico (um manifesto nãocomunista). Rio de Janeiro, Zahar.

ROUANET, Sérgio P. (1994), “Idéias Importadas: Um Falso Problema?”. Cadernos do IPRI, no 15 , pp. 31-40. 
SANTOS, Wanderley G. dos. (1978), Ordem Burguesa e Liberalismo Político. São Paulo, Duas Cidades.

SCHMIDT, Volker. (2007), “Modernidades Múltiplas ou Variedades da Modernidade?". Revista de Sociologia e Política, no 28, pp. 147-160.

. (2012), "Conceptualizing Global Modernity. A Tentative Skecth". Working Paper Series, Departamento de Sociologia, National University of Singapore, pp. 1-52.

SCHWARCZ, Lilia. (1993), O Espetáculo das Raças: Cientistas, Instituições e Questão Racial no Brasil - 1870-1930. São Paulo, Companhia das Letras.

e BOTELHO, André. (2008), "Ao Vencedor as Batatas 30 Anos: Crítica da Cultura e Processo Social: Entrevista com Roberto Schwarz". Revista Brasileira de Ciências Sociais, vol. 23, no 67, pp. 147-160.

SCHWARZ, Roberto. (2009a) [1972], “As Idéias Fora de Lugar”, in R. Schwarz (org.), Cultura e Política. São Paulo, Paz e Terra, pp. 59-83.

. (2009b) [1986], "Nacional por Subtração", in R. Schwarz (org.), Cultura e Política. São Paulo, Paz e Terra, pp. 109-136.

SUBRAHMANYAM, Sanjay. (1997), “Connected Histories: Notes towards a Reconfiguration of Early Modern Eurasia". Modern Asian Studies, vol. 31, no 3, pp. 735-762.

TAVOLARO, Sergio B. F. (2005), “Existe uma Modernidade Brasileira? Reflexões em torno de um Dilema Sociológico Brasileiro". Revista Brasileira de Ciências Sociais, vol. 20, no 59 , pp. 5-22.

(2011), Cidadania e Modernidade no Brasil: Uma Crítica a um Discurso Hegemônico (1930-1945). São Paulo, Annablume.

. (2013), “Gilberto Freyre e nossa 'Modernidade Tropical': Entre a Originalidade e o Desvio". Sociologias, vol. 15, no 33, pp. 282-317.

TORRES, Alberto. (1982). A Organização Nacional. Brasília, Editora da UnB.

VENTURA, Roberto. (1991), Estilo Tropical: História Cultural e Polêmicas Literárias no Brasil, 1870-1914. São Paulo, Companhia das Letras.

VIANNA, Luiz Werneck. (2004), A Revolução Passiva: Iberismo e Americanismo no Brasil. Rio de Janeiro, Revan.

VIANNA, Oliveira. (1987), Populações Meridionais do Brasil: História, Organização, Psicologia. Belo Horizonte, Itatiaia; Niterói, Editora da UFF.

WAGNER, Peter. (2003), A Sociology of Modernity: Liberty and Discipline. London, Routledge.

WIMMER, Andreas e SCHILLER, Nina. (2002), "Methodological Nationalism and Beyond: Nation-state Building, Migration and the Social Sciences". Global Networks, vol. 2, no 4, pp. 301-334.

WITTROCK, Björn. (2000), “Modernity: One, None or Many? European Origins and Modernity as a Global Condition". Daedalus, vol. 129, no 1, pp. 31-60.

DADOS - Revista de Ciências Sociais, Rio de Janeiro, vol. 57, nº 3, 2014 


\section{RESUMO}

A Tese da Singularidade Brasileira Revisitada: Desafios Teóricos Contemporâneos

A tese da singularidade brasileira é a ideia-força mais penetrante do pensamento social brasileiro. Como nenhuma outra, ela tem logrado circunscrever e orientar a agenda de reflexão e pesquisa acerca da experiência social no país. Vislumbrada como singular em relação a outras, a sociedade brasileira é tornada uma categoria analítica e, na mesma proporção, em um objeto de investigação privilegiado, merecedor de esforços explicativos e interpretativos específicos. Por meio de uma análise de alguns dos mais célebres exercícios de interpretação do Brasil, o presente artigo pretende revisitar essa tese, interpelando-a em algumas de suas principais manifestações, com o propósito inicial de identificar os elementos que a consubstanciam. Almeja, em segundo lugar, avaliar como ela reage aos crescentes desafios lançados contra o discurso sociológico da modernidade por elaborações teóricas contemporâneas, dentre as quais o debate em torno da modernidade global, das modernidades múltiplas, da condição pós-colonial e da decolonialidade do saber/poder.

Palavras-chave: teoria social; teoria sociológica; modernidade; singularidade brasileira; pensamento social brasileiro

\section{ABSTRACT \\ The Notion of Brazilian Singularity Revisited: Contemporary Theoretical Challenges}

The hypothesis of Brazilian singularity is the single most powerful idea in Brazilian social thought. As no other, it has succeeded in circumscribing and shaping the agenda of research and reflection concerning the country's social experience. Conjured up a entirely unique compared to others, Brazilian society is elevated to an analytical category and, in the same measure, a privileged object of investigation, worthy of specific explanatory and interpretive efforts. By means of an analysis of some of the most famous interpretations of Brazil, this article revisits this theory, challenging some of its main manifestations with the initial goal of identifying elements that substantiate the claim. It also aims to assess show responses to a growing number of challenges to the sociological discourse of modernity by contemporary theories, including the debate on global modernity, multiple modernities, the post-colonial condition and the decolonization of knowledge/power.

Keywords: social theory; sociological theory; modernity; Brazilian singularity; Brazilian social thought 


\section{RÉSUMÉ}

\section{La Thèse de la Singularité Brésilienne Revisitée: Défis Théoriques Contemporains}

La thèse de la singularité brésilienne est l'idée-force la plus pénétrante de la pensée sociale brésilienne. Mieux que nulle autre, elle a réussi à jalonner et guider les programmes de réflexion et de recherche sur l'expérience sociale du pays. Vue comme singulière par rapport à d'autres, la société brésilienne est devenue une catégorie à analyser et, pour autant, un objet de recherche privilégié, bénéficiaire d'efforts particuliers d'explication et d'interprétation. Dans cet article, à partir de l'examen de quelques exercices célèbres d'interprétation au Brésil, on cherche à sonder cette thèse en en relevant certaines de ses principales manifestations afin d'identifier les éléments qui lui donnent de la portée. Ensuite, on tente d'évaluer sa réaction face aux croissants défis lancés contre le discours sociologique de la modernité mondialisée, des modernités multiples, de la condition post-coloniale et de la décolonisation du savoir/pouvoir.

Mots-clés: théorie sociale; théorie sociologique; modernité; singularité brésilienne; pensée sociale brésilienne

\section{RESUMEN}

La Tesis de la Singularidad Brasileña Revisitada: Desafíos Teóricos Contemporáneos

La tesis de la singularidad brasileña es la idea fuerza más penetrante del pensamiento social brasileño. Más que ninguna otra formulación, ha logrado circunscribir y orientar la agenda de reflexión e investigación sobre la experiencia social en el país. Vislumbrada como singular respecto a otras, la sociedad brasileña es convertida en categoría analítica y, en la misma proporción, en un objeto de análisis privilegiado, merecedor de esfuerzos explicativos e interpretativos específicos. A través de un examen de algunos de los más célebres ejercicios de interpretación de Brasil, el presente artículo busca revisitar esta tesis, interpelándola en algunas de sus principales manifestaciones, con el propósito inicial de identificar los elementos que la conforman. En segundo lugar, se pretende evaluar cómo ésta reacciona frente a los crecientes desafíos lanzados contra el discurso sociológico de la modernidad por elaboraciones teóricas contemporáneas, incluyéndose aquí el debate sobre modernidad global, modernidades múltiples, la condición postcolonial y la de-colonialidad del saber/poder.

Palabras clave: teoría social; teoría sociológica; modernidad; singularidad brasileña; pensamiento social brasileño 